\title{
Emerging Trends in China's Development of Unmanned Systems
}

Michael S. Chase, Kristen A. Gunness, Lyle J.Morris, Samuel K. Berkowitz, and

Benjamin S. Purser III

\section{Key findings}

- Unmanned systems are emerging as a key area of emphasis for China, one that appears to enjoy considerable national-level funding and support.

- Unmanned vehicles with intelligence capabilities could improve Chinese long-distance targeting.

- Unmanned vehicles with surveillance and reconnaissance capabilities could play a growing role in monitoring territorial disputes at sea.

- As China develops and improves its unmanned-vehicle system production, it is poised to become a global exporter of such systems.
SUMMARY - To better understand trends in Chinese unmanned systems research, development, acquisition, and employment, and their potential implications, RAND undertook exploratory analysis to lay an initial foundation for future research on China's development and use of unmanned systems, including unmanned aerial vehicles (UAVs), unmanned undersea vehicles (UUVs), and unmanned surface vessels (USVs). The exploratory analysis focused on identifying sources related to Chinese development of maritime unmanned systems, including UUVs, USVs, and UAVs, with an emphasis on systems intended for the maritime environment, because of their relevance to maritime territorial disputes in the East and South China Seas; understanding the roles that China sees for unmanned systems; analyzing trends in Chinese development of UUVs, USVs, and maritime UAVs, including the key technologies Chinese researchers are pursuing; exploring how China could employ unmanned systems in its maritime territorial disputes in the East and South China Seas; and identifying areas for further research and potential future developments. The remainder of this report highlights the key findings of this exploratory research project and presents some preliminary analyses of their potential implications. 


\section{INTRODUCTION}

Since the mid-1990s, China has engaged in a comprehensive military modernization program designed to enable its armed forces to deter or win high-intensity regional conflicts, support China's coercive diplomacy in its maritime territorial disputes, and conduct other types of military operations as required to protect China's growing global interests. ${ }^{1}$ Beijing has prioritized the development of naval, air, missile, space, and cyber warfare capabilities, an approach that reflects its judgment that it must prepare for U.S. military intervention in a conflict involving Taiwan or China's maritime territorial disputes in the East or South China Seas. ${ }^{2}$ Within this broader context, unmanned systems are emerging as a key area of emphasis for China, and Beijing has made dramatic progress in recent years, as measured by the emergence of a wide variety of new platforms. ${ }^{3}$ Chinese advances are most evident in unmanned aerial vehicles (UAVs), an area in which China has made substantial investments for a number of years, but Beijing is also accelerating its development of unmanned undersea vehicles (UUVs) and unmanned surface vessels (USVs). ${ }^{4}$

China's focus on unmanned systems is at least partially attributable to their potential utility in maritime territorial disputes, but unmanned systems could also be useful to China's military in a range of other contingencies, including domestic disaster relief operations. Chinese government agencies are also

\section{China may envision} exports of unmanned systems as a profitable way of improving its position in the global arms market and a means of strengthening its diplomatic and security ties with recipient countries. finding ways to use unmanned systems for domestic applications, such as industrial pollution monitoring, and Chinese companies are exploring the use of unmanned systems for package delivery. In addition, China may envision exports of unmanned systems as a profitable way of improving its position in the global arms market and a means of strengthening its diplomatic and security ties with recipient countries.

This exploratory analysis was conducted within RAND's Intelligence Policy Center (IPC) and focuses on identifying sources related to Chinese development of maritime unmanned systems, including UUVs, USVs, and UAVs.

\section{ROLES FOR UNMANNED SYSTEMS}

Chinese publications on unmanned systems highlight a number of potential roles. These include intelligence, surveillance, and reconnaissance (ISR); maritime surveillance, particularly in the East China Sea (ECS) and South China Sea (SCS); border surveillance; military communications relay; electronic warfare (EW); mine warfare/mine countermeasures; combat applications/strike missions; and humanitarian assistance and disaster relief (HA/DR) missions, such as imaging areas struck by earthquakes.

The available Chinese literature suggests that ISR applications are a primary focus of industry. Long-range UAVs or UUVs could be used for over-the-horizon (OTH) targeting for People's Liberation Army Navy (PLAN) ships during wartime. Shorter-range tactical UAVs/UUVs could conduct ISR on assets on Taiwan, as well as ships in the ECS/SCS. Medium-altitude or high-altitude UAVs (medium altitude, long endurance [MALE] and high altitude, long endurance [HALE]) could conduct broad-area surveillance at extended ranges and provide early warning capability. Unmanned systems can also be employed for maritime surveillance, not only by the People's Liberation Army (PLA) but also by Chinese maritime law enforcement agencies. Chinese sources highlight the importance of building infrastructure to support future use of UAVs for maritime surveillance, and China has already used UAVs around the disputed Senkaku/ Diaoyu Islands. Employment of unmanned systems for domestic HA/DR missions is another area of emphasis, as highlighted by reports about such systems' use during the 2008 Sichuan earthquake, and unmanned systems could also support future international HA/DR missions. Other military applications could include communications relay, EW, and power grid attack. ${ }^{5}$ 


\section{The available Chinese literature suggests that ISR applications are a primary focus of industry.}

Some uncertainties with respect to future roles could include the potential implications of ongoing policy debates for employment of unmanned systems. For example, there has been robust debate among Chinese think tanks, and also likely the leadership, over China's use of unmanned systems in lethal nonwartime situations. This debate was pushed to the forefront after details emerged in February 2013 that China had considered launching a drone strike in Myanmar to kill a drug trafficker who was wanted for killing 13 Chinese sailors in 2011. Beijing abandoned the plan, in part because the leadership was afraid of sparking international controversy. ${ }^{6}$

\section{OVERVIEW OF CHINESE UUVS AND USVs}

Chinese interest in UUVs appears to have increased dramatically in recent years. ${ }^{7}$ Indeed, over the past few years, China has reportedly increased its emphasis on unmanned marine systems, with at least 15 teams set up at major universities and research institutes to conduct research on UUVs and USVs, and a dramatic surge in government funding, coming mainly from the PLA. Key research areas reportedly include development of imaging systems and communications technology.

Chinese researchers are focusing on a wide range of civil and military applications for unmanned maritime systems. According to Professor Ma Zhongli, a robotics expert at Harbin Engineering University, important civil applications include environmental protection and fisheries management, but "the government's biggest interest is in the application's use in the military."

In addition to numerous articles on foreign technological developments, Chinese scientific and technical journals, other periodicals, and websites discuss a number of Chinese UUVs, including the following systems: "Zhishui 3" UUV prototype with dual-tail propellers and two cross-tunnel thrusters; SPC-3

\section{Abbreviations}

$\begin{array}{ll}\text { AUV } & \text { autonomous underwater vehicle } \\ \text { BBS } & \text { bulletin board system } \\ \text { CSIC } & \text { China Shipbuilding Industry Corporation } \\ \text { DoD } & \text { U.S. Department of Defense } \\ \text { ECS } & \text { East China Sea } \\ \text { EW } & \text { electronic warfare } \\ \text { HA/DR } & \text { humanitarian assistance and disaster relief } \\ \text { HALE } & \text { high altitude, long endurance } \\ \text { ISR } & \text { intelligence, surveillance, and reconnaissance } \\ \text { MALE } & \text { medium altitude, long endurance } \\ \text { NASIC } & \text { National Air and Space Intelligence Center } \\ \text { OTH } & \text { over the horizon } \\ \text { PLA } & \text { People's Liberation Army } \\ \text { PLAAF } & \text { People's Liberation Army Air Force } \\ \text { PLAN } & \text { People's Liberation Army Navy } \\ \text { PRC } & \text { People's Republic of China } \\ \text { SCS } & \text { South China Sea } \\ \text { SOA } & \text { State Oceanic Administration } \\ \text { UAV } & \text { unmanned aerial vehicle } \\ \text { UCAV } & \text { unmanned combat aerial vehicle } \\ \text { USV } & \text { unmanned surface vehicle } \\ \text { UUV } & \text { unmanned undersea vehicle }\end{array}$

robofish UUV prototype (Beijing University of Aeronautics and Astronautics); Haiyan glider-type UUV (Tianjin University); bionic flapping-wing UUV (College of Maritime Studies, Northwestern Polytechnical University of Xi'an); flexible double-tail fin UUV (Department of Modern Mechanics, University of Science and Technology of China, Hefei); and UUVs armed with torpedoes (Department of Weaponry Engineering, Naval University of Engineering, Wuhan).

A review of Chinese journals, other publications, and industry websites indicates that the key defense industrial organizations involved in UUV research include China Shipbuilding Industry Corporation (CSIC) and some of its various subordinate institutes, such as Jiangsu Automation Research Institute, Lianyungang; CSIC No. 710 Research and Development Institute, Yichang; CSIC No. 704 Research and Development Institute; Northwestern Polytechnical University, Xi'an Shanxi; Tianjin University; University of Science and Technology of China, Hefei; and Naval University of Engineering, Wuhan. 


\section{The development of unmanned systems appears to enjoy considerable national-level funding and support in China.}

There are also several specially designated "key labs" involved in UUV research and development, including National Key Laboratory of Science and Technology on Underwater Information Process and Control; College of Marine Studies, Northwestern Polytechnical University, Xian; Key Laboratory for Hydrodynamics and Ocean Engineering, Institute of Mechanics, Chinese Academy of Sciences, Beijing; State Key Laboratory of Underwater Acoustic Technology, Harbin Engineering University; Key Laboratory of Underwater Acoustic Communication and Marine Information Technology,

Ministry of Education, Xiamen; and National Key Laboratory of Science and Technology on Underwater Acoustic Warfare, Shanghai. In contrast to numerous articles on UUVs, however, we found relatively little information on Chinese development of USVs.

\section{OVERVIEW OF CHINESE UAVs}

China already deploys a number of UAVs, including various short-range systems; several types of tactical UAVS, such as the ASN-209 tactical UAV system; and strategic UAVs, such as the BZK-005, a medium-altitude long-endurance reconnaissance UAV developed by Beihang University. The PLA clearly aims to improve on these capabilities. Indeed, according to the National Air and Space Intelligence Center (NASIC), "China has been developing a wide range of UAVs including long-range and low-observable systems that are capable of conducting reconnaissance and strike missions." That unmanned airborne systems are emerging as an increasingly important area of emphasis for the Chinese military is reflected by the plethora of photos of different UAV and unmanned combat aerial vehicle (UCAV) systems that have appeared on the Internet over the past few years. One prominent example is a long-endurance reconnaissance UAV that was revealed on Chinese websites in late $2013 .{ }^{10}$ Indeed, according to the U.S. Department of Defense (DoD), within this past year alone, "China unveiled details of four UAVs under development, three of which are designed to carry weapons." ${ }^{11}$ Among the numerous Chinese
UAVs under development, some of the most notable include the Soaring Dragon (Xianglong), which resembles the U.S. Global Hawk surveillance UAV; Pterodactyl (Yilong), which resembles the U.S. Predator and Reaper drones; and Sharp Sword (Lijian), a stealthy UAV with a flying wing design. The development of these and other systems reflects progress in China's aviation industry more broadly and suggests a growing emphasis on exports of systems like the Pterodactyl UAV. ${ }^{12}$ Additionally, DoD judges that China's "acquisition and development of longer-range UAVs will increase China's ability to conduct long-range reconnaissance and strike operations." ${ }^{\text {13 }}$

For their part, People's Liberation Army Air Force (PLAAF) officers and other Chinese analysts argue that China should continue to develop advanced UAVs to perform a wide range of missions. For example, Huang Sujian and Zhang Zhengping highlight the need for the PLAAF to develop combat platforms that are "unmanned, stealthy, and informatized." ${ }^{14}$ Chinese analysts continue to publish a large volume of research in areas related to UAVs, ${ }^{15}$ and numerous Chinese defense industry organizations are involved in UAV research. ${ }^{16}$ These include the following: Nanjing University of Aeronautics and Astronautics; Nanjing Research Institute on Simulation Techniques/PLA General Staff Department 60th Institute; Northwestern Polytechnic University; Xi'an ASN Technology Group; Beijing Wisewell Avionics Science and Technology Company; Beijing University of Aeronautics and Astronautics; China Aerospace Science and Technology Corporation; China Aerospace Science and Industry Corporation; Aviation Industries of China) (UAV R\&D; production base for PLA UAVs); and China Electronic Technology Corporation (CETC).

\section{NATIONAL-LEVEL FUNDING AND SUPPORT}

The development of unmanned systems appears to enjoy considerable national-level funding and support in China. For the Chinese military's unmanned systems programs, the PLA's General Armament Department and General Staff Department 
appear to play key roles in providing top-level guidance. Other parts of the Chinese government also play important roles in supporting unmanned systems research that could have important defense and national security applications, as reflected by the inclusion of a number of unmanned systems technology R\&D projects under China's National High Technology Research and Development Program, also known as the 863 Program. For example, in April 2013, the People's Republic of China (PRC) Ministry of Science and Technology released a list of marine technology and $R \& D$ projects to be carried out under the 863 Program for 2014, including unmanned "wave glider” autonomous observing systems; long-range hybrid unmanned boat monitoring systems; ship-borne UAV ocean observing systems; and autonomous underwater vehicle (AUV) navigation observation network technology. ${ }^{17}$

\section{UNMANNED SYSTEMS AND MARITIME DISPUTES}

Chinese researchers clearly see important uses for maritime unmanned systems in China's maritime territorial disputes. According to Harbin Engineering University's Professor Ma, "China shares the sea with many countries nearby. In these troubled waters, unmanned vessels can be more effective, convenient and safe than manned ships in many situations. They will also cost less," and "their power will double if they are deployed with [aerial] drones." ${ }^{.18}$ Although much analysis of Chinese unmanned systems development focuses on military capabilities, civilian use of unmanned systems is emerging as an equally important area, one that could have important implications for China's maritime territorial disputes, especially given that Beijing has relied principally on its civilian mari-

\section{Chinese researchers} clearly see important uses for maritime unmanned systems in China's maritime territorial disputes. time law enforcement apparatus to enforce its claims. ${ }^{19}$ Indeed, in August 2012, the State Oceanic Administration (SOA) announced plans to establish 11 UAV sites in coastal provinces for surveillance by 2015 . This reportedly will include watching for "illegal reclamation activities and dredging." 20

\section{SENKAKU/DIAOYU ISLANDS CASE STUDY}

On September 9, 2013, China deployed an unarmed BZK005 UAV over the Senkaku/Diaoyu Islands, which are under Japan's administrative control but are also claimed by China and Taiwan, prompting Japan to scramble fighter jets in response. ${ }^{21}$ The Chinese deployment of a UAV over disputed territory in the maritime domain offers an important case study in crisis stability and the role of UAVs in maritime territorial conflicts. In response to the UAV deployment, Japanese Defense Minister Itsunori Onodera announced that Japan would "consider shooting down drones that enter Japanese airspace," significantly raising the prospects of escalation in a situation that had up to that point remained contained to lowintensity maneuvering involving Chinese and Japanese coast guard and fishing vessels. ${ }^{22}$ Soon after, Japanese Prime Minister Shinzo Abe approved a plan for the Japan Self-Defense Forces to "engage drones intruding into the country's airspace." ${ }^{.23} \mathrm{In}$ response to Abe's remarks, the Chinese Ministry of National Defense spokesperson stated that shooting down a Chinese UAV would constitute an "act of war" and warned that should Japan do so, China would take "resolute measures to strike back." 24

The case offers an important cautionary lesson in the highstakes dynamics at play with the introduction of UAVs into the conflict zone. Japan's quick and forceful response to the Chinese deployment of a UAV was met by equally forceful language from the Chinese side, highlighted by the warning that any Japanese action resulting in a loss of a UAV would constitute an act of war and would elicit an appropriate response. Chinese actions and statements clearly raised the potential for escalation. ${ }^{25}$ Yet China's approach also raises questions regarding the implications for potential Chinese attacks on U.S. UAVs or satellites. For example, would Chinese policymakers view PLA offensive operations against U.S. unmanned assets as likely to elicit a response similar to the threat China issued in this case? Similarly, is a move toward more-parallel ISR capa- 
bilities and operations by the Chinese a potential lever to influence Chinese attitudes toward U.S. surveillance operations? ${ }^{26}$

\section{OTHER CIVILIAN USES OF}

\section{UNMANNED SYSTEMS IN CHINA}

Some other civilian government agencies in China are also turning to unmanned systems to deal with a variety of domestic problems. Perhaps the most prominent example is the employment of unmanned systems in domestic disaster relief operations. For example, China used drones built by the Chinese Academy of Sciences Institute of Remote Sensing Applications to image earthquake-stricken areas in Lushan in 2013. ${ }^{27}$ Another civilian user is the Ministry of Environmental Protection, which has been using drones to monitor industrial polluters in Beijing, Shanxi, and Hebei. ${ }^{28}$ In addition, testing is reportedly under way for an aerial drone capable of spraying chemicals to freeze pollutants. ${ }^{29}$

Reflecting the importance of nonmilitary uses of unmanned systems, China is reported to have constructed a civilian R\&D drone base in Taiyuan, with an investment of $\$ 322.6$ million. In addition, there is at least some interest in commercial applications of unmanned systems among Chinese companies. For example, SF Express, China's biggest delivery company, is experimenting with drones for package delivery, with the permission of the PRC government. ${ }^{30}$

In August 2014, a Chinese business publication reported that commercial use of UAVs could expand dramatically in the next several years as more Chinese companies enter the market. The report focused on Da-Jing Innovations Science and Technology Company, which produces UAVs for video and photo use, surveillance, and express delivery. ${ }^{31}$ Some of the UAV technology the commercial market is building will undoubtedly prove useful to the PLA, though government and military investment appears to remain the primary driver behind the development of new Chinese UAV technologies.

\section{CONCLUSION AND IMPLICATIONS}

Unmanned systems are attractive because of advantages such as improved performance, increased ability to take risk, and potential cost savings. ${ }^{32}$ Chinese journal articles and media reports highlight many of these potential advantages. Indeed, recent U.S. military operations have demonstrated the utility of unmanned systems, a development that has been closely watched by the PLA, and Chinese analysts clearly see unmanned systems as valuable in a variety of scenarios. Cost savings are also an attractive reason for China to pursue unmanned systems. ${ }^{33}$ It is therefore not surprising that China has made substantial investments in the development of unmanned systems in recent years. This is likely to have important implications in several areas of importance to the United States, including PLA modernization, China's handling of its maritime territorial disputes, and the potential risks of proliferation of unmanned systems.

UAVs that provide better ISR (combined with a more robust satellite network) could improve China's ability to locate enemy targets at greater distances, offering enhanced capability for targeting anti-ship ballistic missiles and other long-range strike systems. Additionally, UAVs, UUVs, and USVs could augment the PLA's capabilities in several areas, such as use of space-based assets and other ISR capabilities for targeting over long distances or providing better ISR in a regional (Taiwan/ ECS/SCS) scenario. Armed systems could also provide strike capabilities. Overall, according to one PRC analyst: "UAVs will increasingly become 'tip of the spear' in modern conflict." ${ }^{34}$ Yet this assessment seemingly neglects the fact that many unmanned systems are dependent on potentially vulnerable

\section{In August 2014, a Chinese business publication reported that commercial use of UAVs could expand dramatically in the next several years as more Chinese companies enter the market.}


space communications systems, which could compromise their ability to operate effectively in the "complex electromagnetic environment" the PLA expects to encounter in future wars. On the other hand, there may also be opportunities for unmanned systems to substitute for vulnerable Chinese space-based ISR and communications systems. Indeed, autonomous systems may offer the PLA some potential advantages in such environments.

Unmanned systems are also very likely poised to play a growing role in monitoring territorial disputes, including in the vicinity of the Senkaku/Diaoyu Islands and in Beijing's disputes with rival claimants in the SCS. Indeed, there appears to be strong potential for establishment or improvement of infrastructure in disputed areas to support UAV/UUV use. SOA is reportedly focusing on developing its infrastructure for unmanned systems operation in the ECS, which could further inflame tensions with Japan. Similar dynamics may unfold in the SCS, where tensions appear set to increase along with Chinese oil exploration, land reclamation, and other related activities. One reason for China to increase its reliance on unmanned systems in these areas is the potential reduction in costs, a point defense industry representatives have emphasized in public comments. For example, Song Hong, a Chinese UAV industry executive from China Eagle, a company that supports the SOA, recently claimed that employment of UAVs could result in a substantial savings when compared with manned platforms. ${ }^{35}$ One potential complication is that escalation might result from China's use of these systems in disputed areas, as demonstrated by the Chinese and Japanese comments about the possibility of shooting down UAVs in the vicinity of the Senkaku/Diaoyu Islands. Chinese thinking on this issue seems to be unclear at this point, based on the limited discussion of escalation management issues in available sources.

Another development that could have worrisome implications for the United States would be the global proliferation of unmanned systems due to China's low pricing and lack of export restrictions. Indeed, China could be well positioned to become the top global source for many countries seeking such systems; some reports state that China will produce over half the world's UAVs by value over the next decade. China reportedly is targeting export markets for the Predator-style CH4 drone, and its low cost could make it an attractive option for a number of countries. ${ }^{36}$ For example, China recently signed a deal with Saudi Arabia for the sale of the domestically produced Wing Loong MALE UAV, which has a wide variety of

\section{Another development that could have worrisome implications for the United States would be the global proliferation of unmanned systems due to China's low pricing and lack of export restrictions.}

military applications, including precision strike and long-duration, long-distance reconnaissance. ${ }^{37}$

\section{AREAS FOR ADDITIONAL RESEARCH AND POTENTIAL FUTURE DEVELOPMENTS}

This pilot project identified several areas for additional research on Chinese development and employment of unmanned systems, as well as potential future developments of interest to analysts and policymakers.

\section{Areas for Additional Research}

Some of the key areas where additional research might yield useful insights include the following: What are the key developments under way in the area of UUVs and USVs? What factors are influencing Chinese thinking on escalation management issues? What are the key sources of funding for unmanned systems programs? What role do the General Armament Department and PLAN, PLAAF, and PLA Second Artillery Force armament departments play in unmanned systems research, development, and acquisition? What is the role and influence of the relevant science and technology committees? What other universities and research institutes are involved in research on unmanned systems and related technologies? To what extent are communities of unmanned systems operators taking shape 
within the PLAN, PLAAF, and Chinese Coast Guard, and do they have senior patrons or sponsors? Which countries are the main potential customers for Chinese unmanned systems exports? To what extent does the PLA plan to employ unmanned systems to augment or substitute for existing ISR and communications capabilities in the event those systems are degraded by adversary counterspace or electronic attacks? What are the implications of China's operation of unmanned systems for Beijing's approach to dealing with U.S. surveillance activities in China's exclusive economic zone? And finally, could increasingly parallel UAV concepts and areas of operation between China and the United States create incentives for restraint on the Chinese side?

\section{Areas to Watch for Future Developments}

Looking beyond these current issues, analysts should watch for a number of potential future developments: Will unmanned systems become an area of even greater emphasis in the future if slowing economic growth places greater pressure on the defense budget? Will organizational culture and bureaucracy stifle or encourage innovation in China's development and employment of unmanned systems? Are there potential Chinese advocates for unmanned systems, either among the operators or at more senior levels in the PLA? Is there a senior PLA officer who might play a critical role in supporting unmanned systems development, as Admiral Liu Huaqing did in advocating for PLAN aircraft carriers? Alternatively, will opposition emerge from communities that view development and deployment of unmanned systems as threatening to their bureaucratic interests, such as budgets for programs that unmanned systems might replace? How will China leverage commercial unmanned systems research with potential applications for future defenseand security-related missions? Will China pursue an approach characterized mostly by innovation in the development and employment of unmanned systems, or will it focus more heavily on copying the United States and other countries? How will China address command and control, communications, and networking challenges? How will China address policy issues related to autonomous capabilities? How will China deal with potential contradictions between technology developments and traditional policy preferences? 


\section{A Note About Sources}

The project team identified a number of Chinese academic and science and technology journals, newspapers, websites, and other secondary sources, such as bulletin board system (BBS) forums and military enthusiast websites, that contain potentially valuable information about Chinese unmanned systems developments. Some of the most valuable Chinese-language publications include: 飞航导弹 [Winged Missile Journal]; 计 算机仿真 [Computer Simulation]; 实验力学 [Experimental Mechanics]; 系统工程与电子技术 [Systems Engineering and Electronics]; 水雷战与舰船防护 [Mine Warfare and Ship Self-Defense]; 舰船电子工程 [Ship Electronic Engineering]; 国 防科技 [National Defense Science and Technology]; 国防技术 基础 [Technology Foundation of National Defense]; 环球军事 [World Military]; and 指挥控制与仿真 [Command Control and Simulation]. We believe these are valuable sources for a variety of reasons, including the institutional affiliations of many of the authors and the connections of some of the journals to China's defense industry. Additionally, an examination of postings related to Chinese air exhibitions, such as the Zhuhai Air Show, as well as BBS chat forums frequented by Chinese military enthusiasts, reveals a number of details about unmanned systems developments, particularly with respect to China's growing UAV industry. For example, The "Yilong," or "Wing Loong" UAV, which is capable of conducting reconnaissance and ground attack missions, was unveiled at the $2012 \mathrm{Zhu}-$ hai Air Show as an inexpensive alternative to U.S. and Israeli models. ${ }^{38}$ In addition, China unveiled its largest domestically produced UAV helicopter — the V-750 — at the 2014 Zhuhai Air Show in November 2014. ${ }^{39}$

\section{Notes}

${ }^{1}$ For China's perspective, see Information Office of the State Council, Diversified Employment of China's Armed Forces, Beijing, China: Information Office of the State Council, 2013. For an overview of the DoD's view of Chinese military modernization, see U.S. Department of Defense, Military and Security Developments Involving the People's Republic of China, 2014, Washington, D.C.: Office of the Secretary of Defense, June 2014.

${ }^{2}$ As China-Taiwan relations have become more stable over the past several years, the East and South China Seas appear to have emerged as the most likely flashpoints, especially with Beijing's recent attempts to use its maritime law enforcement capabilities, fishing vessels, and state-owned oil company assets to coerce rival claimants in the East and South China Seas, particularly Japan, Vietnam, and the Philippines.

${ }^{3}$ U.S. Department of Defense, Defense Science Board, Task Force Report: The Role of Autonomy in DoD Systems, Washington, D.C.: Office of the Undersecretary of Defense for Acquisition, Technology and Logistics, July 2012, pp. 69-71.

${ }^{4}$ Stephen Chen, "After Drones, China Turns to Unmanned Vessels to Boost Its Marine Power," South China Morning Post, December 5 , 2013.

${ }^{5}$ See, for example, Wang Liuyi et al., "Navy's First Use of UAVs in Exercise for Battlefield Long Distance Communications Support" [“海军首次运用无人机战场远程通信支援演练”], PLA Daily Online, July 10, 2011.

${ }^{6}$ Ernest Kao, "China Considered Using Drone in Myanmar to Kill Wanted Drug Lord,” South China Morning Post, February 20, 2013.

${ }^{7}$ Lyle Goldstein and Shannon Knight, "Coming Without Shadows, Leaving Without Footprints," U.S. Naval Institute Proceedings, Vol. 136, No. 4, April 2010, pp. 30-35.

${ }^{8}$ Ma highlights the following advantages of UUVs and USVs: "They can patrol on water tirelessly 24 hours a day, seven days a week. . . . They can be deployed immediately in enormous numbers to overwhelm the enemy. Most importantly, they can reduce casualties. The situation in some waters can become too sensitive or too dangerous to send men in. That's when they need our boats the most." Quoted in Chen, 2013.

${ }^{9}$ Lee Fuell, "Broad Trends in Chinese Air Force and Missile Modernization," presentation to the U.S.-China Economic and Security Review Commission, January 30, 2014, p. 5.

${ }^{10}$ See "Photos of China's First Long-Endurance UAV Released," China.org.cn, November 8, 2013.

${ }^{11}$ U.S. Department of Defense, 2014, p. 33.

${ }^{12}$ Andrew S. Erickson, Hanlu Lu, Kathryn Bryan, and Samuel Septembre, "Research, Development, and Acquisition in China's Aviation Industry: J-10 and Pterodactyl UAV," in Kevin Pollpeter, ed., Getting 
to Innovation: Assessing China's Defense Research, Development, and Acquisition System, La Jolla, Calif.: University of California Institute on Global Conflict and Cooperation, January 2014, pp. 62-66.

${ }^{13}$ U.S. Department of Defense, 2014, p. 33.

${ }^{14}$ Huang Sujian and Zhang Zhengping, "The Development of the Essential Properties of the U.S. Strategic Air Force and Its Inspiration for China's Air Force Building," in Zhu Hui, ed., Strategic Air Force [Zhanlue kongjun lun], Beijing, China: Blue Sky Press, 2009, p. 282.

${ }^{15}$ See, for example, Longsheng Wang et al., "Small UAV for Tracking Sea Surface Target Online Route Planning” ““跟踪海面目标的小型 无人机在线航迹规划”], Second Annual China Aerospace Weapons Conference paper, presented in Xi'an, October 2011, pp. 179-183; Weiyan Wang and Zhengdong Wang, "Research on UAV-Assisted Anti-Ship Missile’s Penetration of Defenses Under Complex Battlefield Conditions” [“复杂战场环境下无人机辅助反舰导弹突防研 究”], Winged Missile Journal (Feihang Daodan), No. 6, 2011, pp. 52-55; Liang Yong et al., "Research on UAV Assisted Over-the-Horizon Anti-Ship Missile Guidance Methods and Simulation” ““反舰导 弹无人机超视距弓[导方法及仿真研究”], 2009 National Simulation Technology Conference paper, presented in Jiujiang, August 2009, pp. 184-186, 255; Feng Xiong et al., "Research on Using UAV Data Link Technology to Elevate Anti-Ship Missile Attack Capability" [“利用无人机中继指导技术提高反舰导弹攻击能力研究”], Winged Missile Journal (Feihang Daodan), No. 8, 2004, pp. 35-37; and Liang Yong et al., "Research on Critical Questions for UAVs in Anti-Ship Missile Data Link Guidance” [“无人机在反舰导弹中继制导中的矢 键问题”], Tactical Missile Control Technology (Zhanshu Daodan Kongzhi Jishu), No. 2, 2009; Rongchun Zhao, Xie Pingwen, et al., "UAV Unit-Quietly Developing a New Military Branch” [“无人机部 队一悄然而生的新兵种”] Global Military (Huanqiu Junshi), No. 158, September 2007; Zhen Zhao, Zhu Li, et al., "Preliminary Analysis of the Use of Anti-Radiation UAVs in Modern Air Attack Combat" [“浅析反辐射无人机 在现代空袭作战中的应用”], Winged Missile Journal (Feihang Daodan), No. 9, November 2013; Zansheng Tan, Kai He, et al., "The Search Method and Search Width of Optical Payload of Shipborne UAV for Sea Target” [“舰载无人机光电载荷对 海搜索方式与搜索宽度”], Command Control and Simulation (Zhihui Kongzhi yu Fangzhen), Vol. 33, No. 6, December 2011; Zhenguo Zhang, Sun Xu, et al., "Feasibility Analysis of UAV Application in Air Force Strategic Early Warning” “无人机用于空军战略预警作 战的可行性分析”], Modern Radar (Xiandai Leida), October 2012; Liu Qing, Cao Zeyang, "Research on the Influence of UAVs on SAM Unit Combat” “无人机对地空导弹部队作战的影响及对策研究”], Winged Missile Journal (Feihang Daodan), No. 10, 2010; and Zhilong Qin and Hua Wang, "The Notional Use of Unmanned Aerial Vehicles to Assist Anti-Ship Ballistic Missile Attacks on Aircraft Carriers" [“利用无人机协助反舰弹道导弹打击航母的设想”], Winged Missile Journal (Feihang Daodan), November 2010, pp. 44-47.

${ }^{16}$ See Kimberly Hsu, "China’s Military Unmanned Aerial Vehicle Industry," U.S.-China Economic and Security Review Commission, June 2013; Ian M. Easton and L. C. Russell Hsiao, “The Chinese
People's Liberation Army's Unmanned Aerial Vehicle Project: Organizational Capacities and Operational Capabilities," Project 2049 Institute, March 2013; and Mark Stokes, "China Evolving Conventional Strategic Strike Capability,” Project 2049 Institute, September 2009.

17 "China to Research Shipborne UAV Ocean Observing System," China News, April 17, 2013.

${ }^{18}$ Chen, 2013.

${ }^{19}$ See Brian Spegele, "Beijing Moves to Bolster Claim in South China Sea," Wall Street Journal, January 9, 2014; and Zachary Hosford and Ely Ratner, "The Challenge of Chinese Revisionism: The Expanding Role of China's Non-Military Maritime Vessels," East and South China Seas Bulletin 8, Center for a New American Security, February $1,2013$.

20 "State Oceanic Administration Plans Drone Patrols for Coastal Areas," South China Morning Post, August 30, 2012; "UAVs to Replace Manned Aircraft in Marine Surveillance," People's Daily, September 1, 2012.

21 "Japan Scrambles Fighter Jets After Drone Flies near Disputed Islands," Agence France-Presse, September 9, 2013.

22 "Japan to Shoot Down Foreign Drones That Invade Its Airspace," Kyodo News, October 20, 2013.

${ }^{23}$ Ankit Panda, "Japan to Shoot Down Foreign Drones," The Diplomat, October 22, 2013.

24 "Chinese Drone Training in Line with International Law, Practice," Xinhua, October 26, 2013.

${ }^{25}$ As one of the reviewers of this report pointed out, one possibility is that Beijing intended the move as a provocation that would give it a pretext for taking more-dramatic action, or at least increasing its pressure on Japan. Moreover, even if Beijing did not intend to provoke a Japanese response as a deliberate escalation of the dispute, Chinese actions still increased the risk of unintended escalation, which could result from an accident involving Chinese and Japanese forces operating in proximity, or from another type of incident that leads to miscalculation or misunderstanding by one or both parties.

${ }^{26}$ For a discussion on these questions, see Mark E. Redden and Phillip C. Saunders, "Managing Sino-U.S. Air and Naval Interactions: Cold War Lessons and New Avenues of Approach," China Strategic Perspectives No. 5, National Defense University, September 2012.

27 "Drones Dispatched to Capture Images of Quake-Hit Regions," Xinhua, April 20, 2013.

28 "China Uses Cameras on Drones to Catch Industrial Polluters Unaware," South China Morning Post, March 11, 2014.

29 "China to Test New Smog-Busting Drone to Help Clear Polluted Skies," South China Morning Post, March 5, 2014.

30 "Drones in China Deliver Packages, Even a Birthday Cake," CNET, September 5, 2013. As of January 20, 2015: 
http:/www.cnet.com/news/

drones-in-china-deliver-packages-even-a-birthday-cake/

31 "Commercial Drone Market Set to Take Off in China," Want China Times, August 2014.

${ }^{32}$ See, for example, Paul Scharre, Robotics on the Battlefield, Washington, D.C.: Center for a New American Security, 2014, pp. 10-18.

${ }^{33}$ Lai Yuchen, "Blue Sky Thinking Colors China's UAV Industry," Xinhua, August 17, 2014.

${ }^{34}$ Zhao, Xie, et al., 2007.

${ }^{35}$ Lai, 2014.

${ }^{36}$ Tianran Xu, "Orders Taken for Chinese Drone," Global Times, November 15, 2012.

${ }^{37}$ Zachary Keck, "China to Sell Saudi Arabia Drones," The Diplomat, May 8, 2014.

38 “'Made in Sichuan' Yilong UAV Unveiled for the First Time” [“四 川造,翼龙无人机首露真容], November 13, 2012, Huaxi Metropolis Daily [华西都市报]; and “Reasons for Happiness and Concern of China's 'Hot UAV Market,” Tiexue Community [铁血社区], online post, January 4, 2012.

39 “China’s Largest Helicopter UAV V-750 Obtains Permissions” [“中 国最大无人直升机V-750首获适航许可”], China International Aerospace Exhibition [中国国际航空航无博览会], September 4, 2014. As of January 20, 2015,

http://www.airshow.com.cn/cn/Article/xyjxx/2014-09-04/19946.html

\section{References}

Chen, Stephen, "After Drones, China Turns to Unmanned Vessels to Boost Its Marine Power," South China Morning Post, December 5 , 2013.

“China’s Largest Helicopter UAV V-750 Obtains Permissions” [“中国 最大无人直升机V-750首获适航许可”], China International Aerospace Exhibition [中国国际航空航无博览会], September 4, 2014. As of December 29, 2014:

http:/www.airshow.com.cn/cn/Article/xyjxx/2014-09-04/19946.html

"China to Research Shipborne UAV Ocean Observing System,"

China News, April 17, 2013.

"China to Test New Smog-Busting Drone to Help Clear Polluted Skies," South China Morning Post, March 5, 2014.

"China Uses Cameras on Drones to Catch Industrial Polluters Unaware," South China Morning Post, March 11, 2014.

"Chinese Drone Training in Line with International Law, Practice," Xinhua, October 26, 2013.

"Commercial Drone Market Set to Take Off in China," Want China Times, August 2014. As of December 29, 2014 :

http://www.wantchinatimes.com/news-subclass-cnt.aspx?id=2014081 2000007\& $\mathrm{cid}=1202$

"Drones in China Deliver Packages, Even a Birthday Cake," CNET, September 5, 2013. As of December 29, 2014:

http://www.cnet.com/news/drones-in-china-deliver-packages-even-abirthday-cake/

"Drones Dispatched to Capture Images of Quake-Hit Regions," Xinhua, April 20, 2013.

Easton, Ian M., and L. C. Russell Hsiao, “The Chinese People's Liberation Army's Unmanned Aerial Vehicle Project: Organizational Capacities and Operational Capabilities," Project 2049 Institute, March 2013. As of December 29, 2014:

http://project2049.net/documents/uav_easton_hsiao.pdf

Erickson, Andrew S., Hanlu Lu, Kathryn Bryan, and Samuel Septembre, "Research, Development, and Acquisition in China's Aviation Industry: J-10 and Pterodactyl UAV," in Kevin Pollpeter, ed., Getting to Innovation: Assessing China's Defense Research, Development, and Acquisition System, La Jolla, Calif.: University of California Institute on Global Conflict and Cooperation, January 2014, pp. 62-66.

Fuell, Lee, "Broad Trends in Chinese Air Force and Missile Modernization," presentation to the U.S.-China Economic and Security Review Commission, January 30, 2014, p. 5.

Goldstein, Lyle, and Shannon Knight, "Coming Without Shadows, Leaving Without Footprints," U.S. Naval Institute Proceedings, Vol. 136, No. 4, April 2010, pp. 30-35. 
Hosford, Zachary, and Ely Ratner, "The Challenge of Chinese Revisionism: The Expanding Role of China's Non-Military Maritime Vessels," East and South China Seas Bulletin 8, Center for a New American Security, February 1, 2013.

Hsu, Kimberly, "China's Military Unmanned Aerial Vehicle Industry," U.S.-China Economic and Security Review Commission, June 2013. As of December 29, 2014:

http://origin.www.uscc.gov/sites/default/files/Research/ China\%27s\%20Military\%20UAV\%20Industry_14\%20June\%20 2013.pdf

Huang Sujian and Zhang Zhengping, "The Development of the Essential Properties of the U.S. Strategic Air Force and Its Inspiration for China's Air Force Building," in Zhu Hui, ed., Strategic Air Force [战略空军论], Beijing, China: Blue Sky Press, 2009, pp. 277-282

Information Office of the State Council, The Diversified Employment of China's Armed Forces, Beijing, China: Information Office of the State Council, 2013.

"Japan Scrambles Fighter Jets After Drone Flies near Disputed Islands," Agence France-Presse, September 9, 2013.

"Japan to Shoot Down Foreign Drones That Invade Its Airspace," Kyodo News, October 20, 2013.

Kao, Ernest, "China Considered Using Drone in Myanmar to Kill Wanted Drug Lord," South China Morning Post, February 20, 2013.

Keck, Zachary, "China to Sell Saudi Arabia Drones," The Diplomat, May 8, 2014.

Lai Yuchen, "Blue Sky Thinking Colors China’s UAV Industry," Xinhua, August 17, 2014.

Liu, Qing, and Cao Zeyang, "Research on the Influence of UAVs on SAM Unit Combat” “无人机对地空导弹部队作战的影响及对策研 究”], Winged Missile Journal (Feihang Daodan) [飞航导弹], No. 10, 2010 .

“'Made in Sichuan' Yilong UAV Unveiled for the First Time” [“四 川造”翼龙无人机首露真容”], Huaxi Metropolis Daily [华西都市报], November 13, 2012. As of December 29, 2014: http://www.wccdaily.com.cn/shtml/hxdsb/20121113/41715.shtml

Panda, Ankit, "Japan to Shoot Down Foreign Drones," The Diplomat, October 22, 2013.

"Photos of China's First Long-Endurance UAV Released," China.org. cn, November 8, 2013. As of December 30, 2014:

http://www.china.org.cn/photos/2013-11/08/content_30535820.htm

Qin, Zhilong, and Hua Wang, "The Notional Use of Unmanned Aerial Vehicles to Assist Anti-Ship Ballistic Missile Attacks on Aircraft Carriers” ““利用无人机协助反舰弹道导弹打击航母的设 想”], Winged Missile Journal (Feihang Daodan) [飞航导弹], November
2010, pp. 44-47.

"Reasons for Happiness and Concern of China's 'Hot UAV Market" Tiexue community [铁血社区], online post, January 4, 2012. As of December 29, 2014: http://bbs.tiexue.net/post2_5662044_1.html

Redden, Mark E., and Phillip C. Saunders, "Managing Sino-U.S. Air and Naval Interactions: Cold War Lessons and New Avenues of Approach," China Strategic Perspectives No. 5, Washington, D.C.: National Defense University, September 2012.

Scharre, Paul, Robotics on the Battlefield, Washington, D.C.: Center for a New American Security, 2014, pp. 10-18.

Spegele, Brian, "Beijing Moves to Bolster Claim in South China Sea," Wall Street Journal, January 9, 2014.

"State Oceanic Administration Plans Drone Patrols for Coastal Areas," South China Morning Post, August 30, 2012.

Stokes, Mark, "China Evolving Conventional Strategic Strike Capability," Project 2049 Institute, September 2009. As of December 29, 2014:

http://project2049.net/documents/chinese_anti_ship_ballistic_ missile_asbm.pdf

Tan, Zansheng, Kai He, et al., "The Search Method and Search Width of Optical Payload of Shipborne UAV for Sea Target” [“舰载 无人机光电载荷对海搜索方式与搜索宽度”], Command Control and Simulation [指挥控制与 仿真], Vol. 33, No. 6, December 2011.

"UAVs to Replace Manned Aircraft in Marine Surveillance," People's Daily, September 1, 2012.

U.S. Department of Defense, Military and Security Developments Involving the People's Republic of China 2014, Washington, D.C.: Office of the Secretary of Defense, June 2014.

U.S. Department of Defense, Defense Science Board, Task Force Report: The Role of Autonomy in DoD Systems, Washington, D.C.: Office of the Undersecretary of Defense for Acquisition, Technology and Logistics, July 2012, pp. 69-71.

Wang, Liuyi, et al., "Navy's First Use of UAVs in Exercise for Battlefield Long Distance Communications Support” [“海军首次运用无人 机战场远程通信支援演练”], PLA Daily Online, July 10, 2011.

Wang, Longsheng, et al., "Small UAV for Tracking Sea Surface Target Online Route Planning” ““跟踪海面目标的小型无人机在线航迹 规划”], Second Annual China Aerospace Weapons Conference paper, presented in Xi'an, October 2011, pp. 179-183.

Wang, Weiyan, and Zhengdong Wang, "Research on UAV-Assisted Anti-Ship Missile's Penetration of Defenses Under Complex Battlefield Conditions” ““复杂战场环境下无人机辅助反舰导弹突防研 
究”], Winged Missile Journal (Feihang Daodan) [飞航导弹], No. 6, 2011, pp. 52-55.

Xiong, Feng, et al., "Research on Using UAV Data Link Technology to Elevate Anti-Ship Missile Attack Capability” [“利用无人机中 继指导技术提高反舰导弹攻击能力研究”], Winged Missile Journal (Feihang Daodan) [飞航导弹], No. 8, 2004, pp. 35-37.

Xu, Tianran, "Orders Taken for Chinese Drone," Global Times, November 15, 2012.

Yong, Liang, et al., "Research on Critical Questions for UAVs in Anti-Ship Missile Data Link Guidance” [“无人机在反舰导弹中继 制导中的矢键问题”], Tactical Missile Control Technology (Zhanshu Daodan Kongzhi Jishu), No. 2, 2009.

Yong, Liang, et al., "Research on UAV Assisted Over-the-Horizon Anti-Ship Missile Guidance Methods and Simulation” [“反舰导弹 无人机超视距引 [导方法及仿真研究”], 2009 National Simulation Technology Conference paper, presented in Jiujiang, August 2009, pp. 184-186, 255.

Zhang, Zhenguo, Sun Xu, et al., "Feasibility Analysis of UAV Application in Air Force Strategic Early Warning” “无人机用于空军战略 预警作战的可行性分析”], Modern Radar, [现代雷达], October 2012.

Zhao, Rongchun, Xie Pingwen, et al., "UAV Unit—Quietly Developing a New Military Branch” [“无人机部队一悄然而生的新兵种”] 环 球军事 [Global Military], No. 158, September 2007.

Zhao, Zhen, Zhu Li, et al., "Preliminary Analysis of the Use of AntiRadiation UAVs in Modern Air Attack Combat” [“浅析反辐射无 人机 在现代空袭作战中的应用”], Winged Missile Journal (Feihang Daodan) [飞航导弹], No. 9, November 2013. 


\section{About This Report}

This exploratory analysis focuses on identifying sources related to Chinese development of maritime unmanned systems, including UUVs, USVs, and UAVs.

This research was conducted within the Intelligence Policy Center of the RAND National Defense Research Institute, a federally funded research and development center sponsored by the Office of the Secretary of Defense, the Joint Staff, the Unified Combatant Commands, the Navy, the Marine Corps, the defense agencies, and the defense Intelligence Community.

For more information on the Intelligence Policy Center, see http://www.rand.org/nsrd/ndri/centers/intel.html or contact the director (contact information is provided on the web page).

\section{Limited Print and Electronic Distribution Rights}

This document and trademark(s) contained herein are protected by law. This representation of RAND intellectual property is provided for noncommercial use only. Unauthorized posting of this publication online is prohibited. Permission is given to duplicate this document for personal use only, as long as it is unaltered and complete. Permission is required from RAND to reproduce, or reuse in another form, any of our research documents for commercial use. For information on reprint and linking permissions, please visit www.rand.org/pubs/permissions.html.

For more information on this publication, visit www.rand.org/t/rr990.

(C) Copyright 2015 RAND Corporation

The RAND Corporation is a research organization that develops solutions to public policy challenges to help make communities throughout the world safer and more secure, healthier and more prosperous. RAND is nonprofit, nonpartisan, and committed to the public interest.

RAND's publications do not necessarily reflect the opinions of its research clients and sponsors. RAND ${ }^{\circledR}$ is a registered trademark.

\section{www.rand.org}

